\title{
Investigations into Ecological Consequences and Threats from Ethnoecological and Ethnobotanical Practices across Karakorum Mountain Ranges: A Case Study Berberis
}

\author{
TIKA KHAN ${ }^{1 *}$, IMTIAZ AHMED KHAN ${ }^{2}$ and ABDUL REHMAN ${ }^{2}$ \\ ${ }^{1}$ Integrated Mountain Area Research Centre, Karakoram International University, Pakistan. \\ ${ }^{2}$ Department of Biological Sciences, Karakoram International University, Pakistan. \\ http://dx.doi.org/10.12944/CWE.9.3.20
}

(Received: November 21, 2014; Accepted: December 09, 2014)

\begin{abstract}
Geomorphologically inaccessible mighty mountain ranges of Karakoram, Hindukush, Himalaya and Pamir have been mother sanctuaries for several ecologically attuned civilizations. Modern changes underway across ethnoecological and ethnobotanical settings among these mountain traditional communities have drastically depreciated folk wisdom and ecological equilibrium. Ethnoclimatic agencies have threatened several species and Berberis pseudumbellata subsp. gilgitica has become critically endangered. Present study was an attempt to discover ethnobotanical insights and exploration of threatening factors affecting Berberis species. Survey $(n=373)$ revealed that communities use Berberis meeting various purposes including medicinal $(92.2 \%$; SE $\pm 0.057 ; 0.409$ MT/annum-a), firewood (19.3\%; SE $\pm 37.375 ; 6.589 \mathrm{MT} / \mathrm{a})$, commercial $(2.41 \%$; SE $\pm 1.692 ; 0.048$ MT/a), cultural (2.41\%), fodder (16.08\%; SE $\pm 11.474 ; 8.724 \mathrm{MT} / \mathrm{a})$, fencing (19.03\%; SE $\pm 6.895 ; 3.352$ MT/a) and grazing (100\%; SE \pm 1.035$)$. Data was analyzed using Pearson correlational coefficient, student t-test and descriptive statistical tools. Study exhibits highly significant relationship $(p<0.000)$ among different age groups, ethnomedicinal uses and conservation status of Berberis.
\end{abstract}

Key words: Berberis, Medicinal Plants, Ethnobotany, Ethnoecology, Karakoram, Critically

\section{INTRODUCTION}

Indigenous communities around the world are a great source of advancement in health care for humanity (Basak et al. 2010; Muthu et al. 2006; Makkar et al. 2007). Ethnobotany compliments ethnopharmacological practices which have enhancing effect on advancement of modern medicine used to treat most pressing medical issues faced by the humanity today (Sheng-Ji 2001). Berberis is one of the important medicinal plant used as a very common ingredient in herbal medication systems viz; Eastern, Ayurvedic, Unani and modern system of medicines (Sing et al., 2008, Chopra et al., 1981; Chandra and Purohit, 1980). It has been reported useful in treatment of cancer, diabetes, jaundice, enlargement of spleen, AIDS, osteoporosis, cardiovascular ailments, ocular trachoma, hypertension, infectious diseases, cholera, diarrhea, dysentery, eye troubles, leprosy and bone fractures etc. (Khan et al., 2013; Sing et al., 2008; Asif et al., 2007; Fatehi et al., 2005; Caraballo et al., 2004; Kuo et al., 2004; Villinski et al., 2003; Janbaza and Gilanib, 2000; Hwang et al., 2002; Ivanoska and Philipov, 1997; Koo and Seang, 1996; Chopra et al., 1981; Chandra and Purohit, 1980).

Berberidaceae is a small family of woody dicotyledonous plants comprising upon c. 15 genera, c. 13 genera are considered established. Genus Berberis is the most prominent among all other having approximately 650 species (Khan et. al. 2014; Perveen and Qaiser 2010; Bottini et al. 2007; Duke et al. 2002; Loconte, 1993; Loconte, 1984). Members of genus Berberis are widely distributed in the Northern Hemisphere (Perveen and Qaiser 2010; Loconte, 
1993). There are 29 Berberis species have been identified from Pakistan. Berberis pseudumbellata subsp. gilgitica is endemic to Gilgit-Baltistan and has become critically endangered (Khan et al. 2014; Alam and Ali 2010). Different ethno-lingual races in the study area use two local names commonly to call Berberis i.e. 'Ishkeen and Churkuye'. Almost 70-75\% population calls it 'Ishkeen'. Shina language is widely spoken language in the area.

Inventorying of ethnobotanically valuable flora is an important first step to understand the ethnomedicinal and socio-cultural significance of plant species (El-Hilaly et al. 2003; Sheng-Ji 2001; Phillips and Gentry 1993; Sher and Hussain 2009). However, detailed investigation of each plant species would reveal more important insights in relation to socio-cultural, ecological, religious and commercial aspects (Deil et al. 2005; Taylor et al. 2001). Such a detailed study of individual species may enable development and academic communities to exploit them wisely to impact poverty, market marginalization and potential advancement in creation of alternatives towards health care practices (Garrity 2004; Roe and Elliott 2004; Scherl 2004; Reynolds et al. 2005).

Plant-human interaction around these naturally variegated valleys is an integrally intertwined and interwoven aspect of rural lives. It is therefore, traditional communities are mostly dependent on the natural resources for meeting their medicinal, food, shelter, economic and other livelihood purposes (Ali et al. 2008; Khan and Khatoon 2007; Pie and Manandhar 1987). Ethnobotanical investigations are important not only for health care but also critical to establish and continue an ecological balance between human and nature (Balée 1994; Gómez Baggethun et al. 2010).

A growing number of ethnobotanists and anthropologists have univocally reported fast erosion of ethnobotanical folk wisdom around the world (Khan et al. 2013a; Sheng-Ji 2001; Begossi et al. 2002; Case et al. 2005; Lozada et al. 2006; Monteiro et al. 2006; Ferguson and Messier 1997; Pieroni et al. 2004; Shanley and Rosa 2004; Anderson 2005; Zent 2001; Turner and Turner 2008; Khan et al. 2013; Hamayaun 2005). According to Hocking (1958) people among these traditional communities were $84 \%$ dependent on their indigenous folk medication practices. However, Khan et al. (2013) reported that in Hunza Valley people have lost ethnomedication practices and only a minor fragment $(1.4 \%)$ use to practice.

Present study was aimed at documentation and exploration of perceptions, practices and other ethnobotanical prospects of Berberis species among these agro-pastoral communes living in Karakoram Mountain Ranges. In present scenario, these societies need special attention to explore them scientifically which has never been realized before (Qureshi et al., 2006). Any delay on this part can lead to their annihilation in the hands of weathering forces of globalization.

\section{MATERIAL AND METHODS}

\section{Geo-cultural landscape of study area:}

Study focused 27 villages across western part of Central Karakoram National Park (CKNP). These villages were grouped into three major valleys viz; Bagrot, Rahimabad-Naltar and Rakaposhi (Nagar). CKNP was declared as National Park in 1993. It is situated in Gilgit-Baltistan, Pakistan and stretches across four administrative districts: HunzaNagar, Gilgit, Skardu, and Ghanche. It is the largest protected area $\left(10,000 \mathrm{~km}^{2}\right)$ in Pakistan having biggest glacial mass in the world outside poles. It extends over $35^{\circ} \mathrm{N}$ to $36.5^{\circ} \mathrm{N}$ Latitude and from $74^{\circ} \mathrm{E}$ to $77^{\circ} \mathrm{E}$ Longitude (Khan et al. 2014).

Area is inhabited by 16 major tribes speaking four different languages of distinct origins i.e. Shina, Brushaski, Gujari, Domaki. Settlements start from the river bed to sub-alpine zones $(1300 \mathrm{~m}$ to $3500 \mathrm{~m}$ above sea level). Most recently, most of the area is accessible by jeep connected through link roads or pony tracts. However, more than 13 villages have become connected with Karakoram Highway constructed in seventies (1970s).

\section{Data collection and sampling}

Sample frame was consisting upon three (3) major valleys stretched over 27 villages with 5480 households. A total of 52,048 souls are living in the study area. Population is living in small and medium sized settlements (villages) with dense or sparse distribution. 
Using following mathematical calculations and sample size (ss) calculator, a total of 382 (male $197,52.81 \%$; female $176,47.18 \%$ ) sample size was calculated. However, during the course of study only 373 individuals were interviewed. This makes $97.6 \%$ of the total sample size drawn. Sample size (both male and female) was divided into three age groups each making a total of six (6) different groups i.e. below thirty ( $d$ "30 $=130,34.85 \%)$, in-between 31 and 60 (e"31d"60 = 143, 38.33\%) and above 61 $(\mathrm{e} " 61=100,26.80 \%)$.

$$
\mathrm{sS}=\frac{z^{2} *(p) *(1-p)}{c^{2}}
$$

Where $Z$ = Z value (e.g. 1.96 for $95 \%$ confidence level); $p=$ percentage picking a choice, expressed as decimal ( 0.5 used for sample size needed); c = confidence interval, expressed as decimal (e.g., $0.04= \pm 4$ )

\section{Sampling type}

During the survey, stratified random sampling technique was employed across purposefully categorized geographic, gender and age strata.

\section{Data collection}

A detailed structured instrument was used to collect uniform data from different strata of sample. Personal observations were also recorded to supplement the questionnaire data collection (Kvist et al.2001). Questionnaire was oriented to maximize quantification of responses (Fraser and Junqueira 2010).

\section{Data processing and analysis}

Data gathered using instrument was digitized into MS Excel 2010 and then transferred to SPSS v.16.1. Various descriptive and inferential techniques were applied to analyze data including frequencies, standard error of mean, Pearson correlational coefficient, student t-test and regression analysis were performed.

\section{RESULTS AND DISCUSSION}

\section{Ethnobotanical use categories}

Communities in the study area use Berberis for various reasons and purposes. These needs can be categorized into at least six (6) broad classes viz; medicinal, firewood, fencing, grazing, fodder, commercial and cultural. Culture use in negligible and infrequent $(n=9 ; 2.41 \%)$. Research did not find any use of Berberis for construction. Details of remaining five categories are given below;

\section{Quantities used as medicine}

Respondents identified 28 distinct quantities used differentially as medicine. Most frequent annually used quantities are; $1.4 \mathrm{~kg}(\mathrm{n}=119,33.9$ $\%), 1.0 \mathrm{~kg}(\mathrm{n}=54,15.5 \%), 0.25 \mathrm{~kg}(\mathrm{n}=47,13.4 \%)$ and $0.5 \mathrm{~kg}(\mathrm{n}=25,7.1 \%)$. Remaining 24 varied categories ranging from $0.019 \mathrm{~kg}$ to $6.8 \mathrm{~kg}$, which are uncommon. On an average each household in the area uses $1.17 \mathrm{~kg}$ annually (fig. 2).

\section{Quantities used as firewood}

During the study $19.3 \%(n=72)$ responded to the question regarding Berberis quantities use for firewood purpose at household level. Respondents mentioned 11 different quantities i.e. 8, 10, 15, 20, 24, 30, 32, 35, 36, 82.8 and 1600. Among these 11 quantitative categories, $36 \mathrm{~kg}(\mathrm{n}=24,6.4 \%$ and valid $\%=33.3$ ) is the most frequent quantity used among the communities followed by $10 \mathrm{~kg}(\mathrm{n}=19,5.1 \%$ and valid $\%=26.4)$ and $15 \mathrm{~kg}(\mathrm{n}=9,2.4 \%$ and valid $\%$ $=12.5$ ). Remaining quantitative categories used have less than $1 \%$ ( $\mathrm{d}$ " 3 , and valid $\%$ d" 4.2 ) for each. Data representation shows that people most commonly use quantities in-between $10 \mathrm{~kg}$ and $36 \mathrm{~kg}$ for their fire purpose at houses (Fig. 3). In the valley of Bagrot a total of $2244.8 \mathrm{~kg}$ (2.244 MT, 34.02\%) is used as firewood at household annually. Similarly, in Rahimabad-Naltar total quantity is $4311.6 \mathrm{~kg}$ (4.311 MT, 65.34\%) and in Rakaposhi it is only 42 kg $(0.63 \%)$.

\section{Quantities sold annually}

Out of total $(n=373)$ respondents, only $2.4 \%(n=9)$ interviewee replied to the question 'what quantities of Berberis they sell every year on an average?' $97.6 \%(n=364)$ left this question without any reply, which was considered as missing data when processed using SPSS for calculations and analysis. These mottled quantities range in-between $1 \mathrm{~kg}$ and $12 \mathrm{~kg}$. Moreover, these quantities are categorized into three (3) groups i.e. $1 \mathrm{~kg}, 3 \mathrm{~kg}$ and $12 \mathrm{~kg}$. Out of total respondents which are more or less involve in sale of Berberis hold equal share of 
only $0.8 \%(n=3)$. A total sale during 2012-13 was only $48 \mathrm{~kg}$. Among three major valleys, Bagrot 16 $\mathrm{kg}(33.33 \%)$ and Rahimabad-Naltar $32 \mathrm{~kg}$ (66.67\%). This study did not record any sale in Nagar Valley.

\section{Quantities used as fodder}

During the study only $16.1 \% \quad(n=60)$ responded to the question. Amongst different quantities used, $150 \mathrm{~kg}(\mathrm{n}=21,35.0 \%), 180 \mathrm{kgs}$ $(n=6,10 \%)$ and $300 \mathrm{kgs}(n=6,10 \%)$ per annum. Remaining categories were less common used by only $5 \%(n=3)$ each. A total of $8724 \mathrm{~kg}$ (8.724 MT) Berberis is collected every year for fodder purpose. Every year in Bagrot, 2908 kg (2.908 MT, 33.33\%) and Rahimabad-Naltar 5486 kg (5.486 MT; 62.88\%) is being collected. Nagar (Rakaposhi) valley as compared to others shows a least trend of using Berberis as fodder i.e. $330 \mathrm{~kg}(3.78 \%)$ annually.

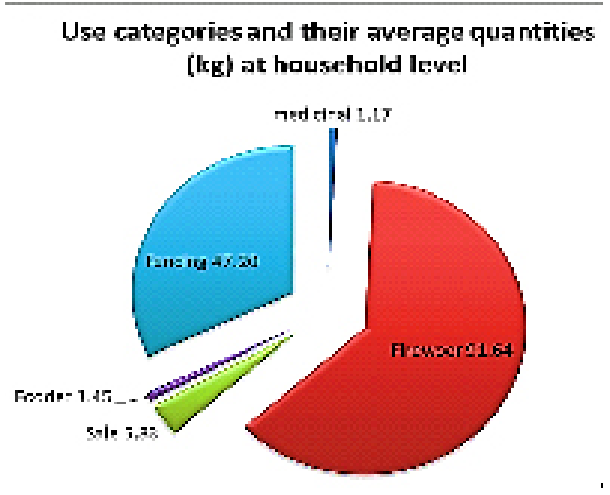

Fig.2 :

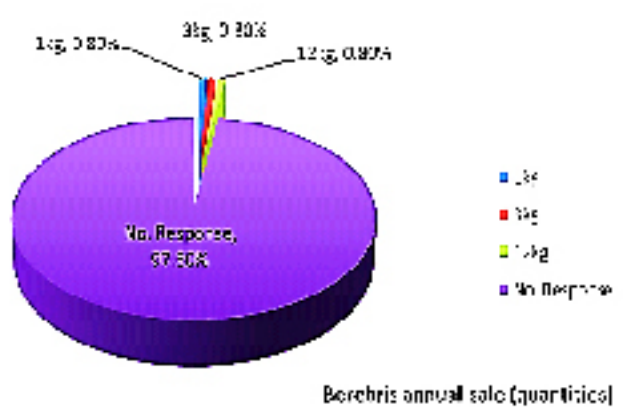

Fig.4 :
Statistical presentation shows a positive but very weak correlation between fodder quantitative ranks and their use frequency. Communities more frequently use quantities ranging between 150-300 kg per annum (Fig. 5).

\section{Quantities used as fencing}

Berberis use for fencing purpose is one of the major consumption sites. Out of total sample size $(n=373)$ only $19.0 \%(n=71)$ responded on the question about Berberis quantities used for fencing. Ten different quantities so expressed range between $12 \mathrm{~kg}$ and $300 \mathrm{~kg}$. among all $20 \mathrm{~kg}(\mathrm{n}=26,7.0 \%$; Valid percent $36.6 \%$ ) is the most frequent consumption quantity followed by $72 \mathrm{~kg}(\mathrm{n}=15,4.0 \%$; Valid percent $21.1 \%), 25 \mathrm{~kg}(\mathrm{n}=9,2.4 \%$; Valid percent $12.7 \%)$ and $15 \mathrm{~kg}(\mathrm{n}=5,1.3 \%$; Valid percent $11.3 \%)$. Remaining six (6) categories showed lesser frequency $(<n=3$,

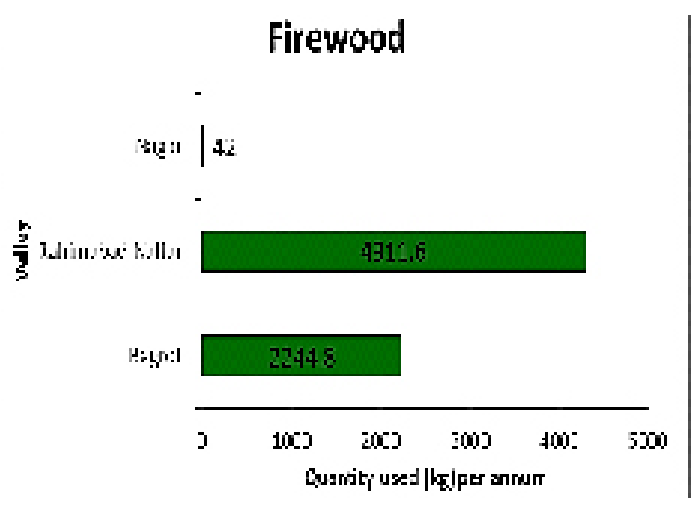

Fig.3 :

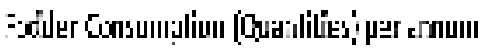

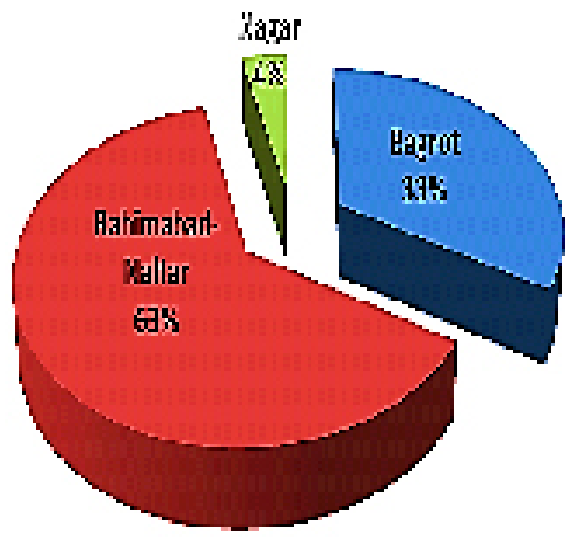

Fig.5 : 


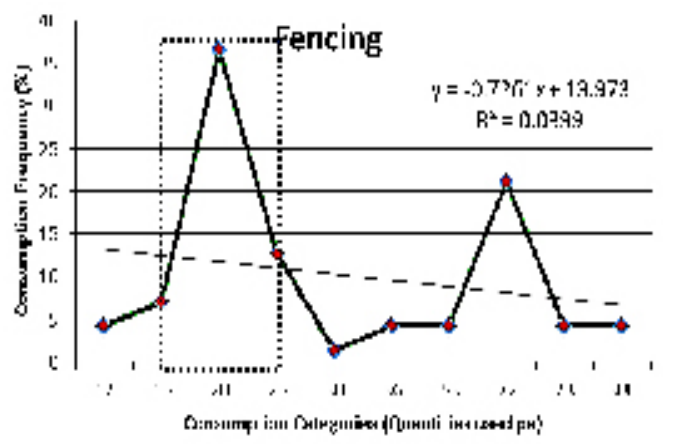

Fig.6 :

$<1.0 \%$; Valid percent $<4.2 \%$ ) of use. A total of 3352 $\mathrm{kg}$ (3.352 MT) is used annually in the area. Each major valley has a varied consumption of Berberis for fencing annually. Rahimabad-Naltar showed highest quantities used for this purpose (1680 kg=1.68 MT; $50.12 \%$ ) followed by Bagrot Valley with second highest quantity (1164 kg = 1.164 MT; 34.73\%). Nagar (Rakaposhi) Valley showed the least utilization of Berberis for fencing with a per annum quantity of 508 kg (0.508 MT; 15.16\%).

Analysis shows a declining linear trend between consumption categories and their respective percentage frequency utilization. Moreover, there is a weak relationship between the two aspects of the parameter under discussion (Fig. 6).

\section{Population dynamics}

For the last fifty (50) years, there is no change in Berberis population ( $n=200,53.6 \%$ ). However, $30.3 \%(n=113)$ still believe that population has changed. Furthermore, $16.1 \%(n=60)$ people told that they do not know whether it has changed or not.

\section{Change direction}

Out of change believers $12.9 \%(n=48)$ told that population has decreased significantly (Fig. 7).

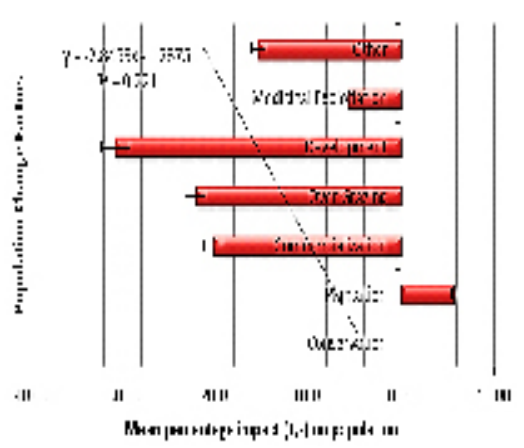

Fig. 7 :

However, $14.5 \%(n=54)$ favor a slight decreased. Whereas, $2.1 \%(n=8)$ interviewee told that the population has increased significantly, for $1,6 \%$ $(n=6)$ there is a slight increase in the population.

\section{Population change factors}

Only $27.9 \% \quad(n=104)$ respondents said that plantation $(n=6: 1.6 \%)$ has healthy contribution towards population growth. However, commercialization ( $n=21: 5.6 \%$ ), over grazing $(n=23: 6.2 \%)$, development activities $(n=32: 8.6 \%)$, medicinal exploitation $(n=6: 1.6 \%)$ and other $(n=16$ : $4.3 \%$ ) factors have negative impact. Population change factor analysis shows that developmental activities are the most ruinous factor followed by over grazing and commercialization, to name top three ones. This change has occurred across all varieties (general) and not to a specific variety. Moreover, this change is $94.23 \%$ unhealthy and only $5.76 \%$ healthy (Fig. 7).

\section{ACKNOWLEDGEMENT}

This study is part of $\mathrm{PhD}$ research. It was not possible without generous financial support from EvK2CNR through SEED-Karakoram International University collaboration.

\section{REFERENCES}

1. Alam J, Ali SI. Contribution to the red list of the Plants of Pakistan. Pakistan Journal of Botany 42(5), 2967-2971 (2010)

2. Ali M, Malik AR, Sharma KR. Vegetative propagation of Berberis aristata DC. An endangered Himalayan shrub. Journal of
Medicinal Plants Research 2(12), pp. 374-377 (2008).

3. Ali, S.I. and M. Qaiser. A phytogeographical analysis of the phanerogams of Pakistan and Kashmir. Proc. Royal. Soc. Edinburgh., 89: 89-101 (1986). 
4. Anderson, T. R. Plankton functional type modeling: running before we can walk? Journal of Plankton Research 27, 1073-1081 ((2005))

5. Asif A, Kabub G, Mehmood S, Khunum R, Gulfraz M. Wound healing activity of root extract of Berberis Lyceum Royle in rats. Phytother. Research 21, 589-591 (2007).

6. Balée, W. Footprints of the forest: Ka'apor ethnobotany. The historical ecology of plant utilization by an Amazonian people ((1994)).

7. Basak, S., Sarma, G. C., \& Rangan, L. Ethnomedical uses of Zingiberaceous plants of Northeast India. Journal of Ethnopharmacology, 132(1), 286-296 ((2010)).

8. Begossi, A.; Hanazaki, N. \& Tamashiro, J.Y. Medicinal plants and the Atlantic Forest (Brazil): knowledge, use and conservation. Human Ecology 30: 281-299 (2002).

9. Bottini, M. C. J., De Bustos, A., Sanso, A. M., Jouve, N., \& Poggio, L. Relationships in Patagonian species of Berberis (Berberidaceae) based on the characterization of rDNA internal transcribed spacer sequences. Botanical Journal of the Linnean Society, 153(3), 321-328 (2007). DOI: 10.1111/j.1095-8339.2007.00586.x

10. Caraballo A, Caraballo B, RodríguezAcosta A. Preliminary assessment of medicinal plants used as antimalarials in the southeastern Venezuelan Amazon. Revista da SociedadeBrasileira de Medicina Tropical 37(2), 186-188 (2004).

11. Case, R. J., G. F. Pauli, and D. D. Soejarto. Factors in Maintaining Indigenous Knowledge among Ethnic Communities of Manus Island. Economic Botany 59: 356-365 (2005).

12. Chandra P, Purohit AN. Berberine contents and alkaloid profile of Berberis species from different altitudes. Biochemical Systematics and Ecology 8(4), 379-380 (1980).

13. Chopra M, Chatterji A, Pakrashi SC. The treatise on Indian medicinal plants CSIR, New Delhi, pp. 33-35 (1981).

14. Deil, U., Culmsee, H., \& Berriane, M. Sacred Groves in Morocco: A Society's Conservation of nature for spiritual reasons'. Silva Carelica, 49, 185-201 (2005).
15. Duke JA, Godwin MB, Decellier J, Duke PA CRC- Hand Book on Medicinal Plants. Taylor and Francis. Inc pub.SBN-13, Edition 2, pp 821 (2002)

16. El-Hilaly, J., Hmammouchi, M., \& Lyoussi, B. Ethnobotanical studies and economic evaluation of medicinal plants in Taounate province (Northern Morocco). Journal of Ethnopharmacology, 86(2), 149-158 (2003).

17. Fatehi M, Saleh TM, Fatehi-Hassanabad Z, Farrokhfal K, Jafarzadeh M, Davodi S. A pharmacological study on Berberis vulgaris fruit extract. Journal of Ethnopharmacology 102(1), 46-52 (2005).

18. Fraser JA, Junqueira AB. How important is a use? Critical reflection on the conceptualization of use and importance in quantitative ethnomedicine In: UP Albuquerque, N Hanazaki (Eds.): Recent Development and Case Studies in Ethno medicine. Brazilian Society of Ethno-biology and Ethno-ecology: Publication Group of Ecology and Applied Ethno-medicine NUPEEA, pp. 113-126 (2010).

19. Ferguson M, Messier F. Collection and analysis of traditional ecological knowledge about a population of Arctic tundra caribou. Arctic. ;50: 17-28 (1997).

20. Garrity, D. P. Agroforestry and the achievement of the Millennium Development Goals. Agroforestry Systems, 61(1-3), 5-17 (2004).

21. Gómez Baggethun, ERIK., Mingorría, S., Reyes García, VICTORIA., Calvet, L., \& Montes, C. Traditional ecological knowledge trends in the transition to a market economy: empirical study in the Donana natural areas. Conservation Biology, 24(3), 721-729 (2010).

22. Hamayaun M. Ethnobotanical Studies of some Useful Shrubs and Trees of District Buner, NWFP, Pakistan. Ethnobotany leaflets (2005).

23. Hocking, G. M. Pakistan Medicinal Plants I, Qualitas Plantarum Et. Material Vegetabiles., 5 : 145-153 (1958).

24. Hussain, I., Bano, A., \& Ullah, F. Traditional drug therapies from various medicinal plants of central Karakoram National Park, GilgitBaltistan, Pakistan. Pak J Bot, 10, 79-84 (2011). 
25. Hwang, Jin-Ming, Wang, Chau-Jong, Chou, Feu-Pi, Tseng, Tsui-Hwa, Hsieh, Yih-Shou, Lin, Wea-Lung, Chu, Chia-Yih. Inhibitory effect of Berberine on tert-butyl hydroperoxideinduced oxidative damage in rat liver. Archives of Toxicology 76(11), 664670 (2002).

26. Ivanoska N, Philipov S. Study on the antiinflammatory action of Berberis vulgaris root extracts, alkaloid fractions and pure alkaloid. International Journal of Immunopharmacology 18(10), 553-561 (1996).

27. Janbaza KH, Gilanib AH. Studies on preventive and curative effects of Berberine on chemicalinduced hepatotoxicity in rodents. Fitoterapia 71(1), 25-33 (2000).

28. Kvist, L.P., S. Gram, A. Cácares and I. Ore , 'Socio-economy of Flood Plain Households in the Peruvian Amazon', Forest Ecology and Management, 150: 175-86 (2001).

29. Khan SW, Khatoon S. Ethnobotanical Studies on useful trees and shrubs of Haramosh and Bagrot valleys, in Gilgit Northern Areas of Pakistan. Pakistan Journal of Botany 39(3), 699-710 (2007).

30. Khan T, Khan IA, Ahmed K, Rehman A. Differential levels of susceptibility of Berberis species to insect attack at various altitudes in Karakoram Ranges. International Journal of Biosciences 4(5), 92-101 2014. DOI: http:// dx.doi.org/10.12692/ijb/4.5.92-101

31. Khan T, Khan IA, Rehman A, Alam J, Ali S. Exploration of near-extinct folk wisdom on medicinally important plants from Shinaki Valley Hunza, Pakistan. International Journal of Biosciences 3(10), 180-186 (2013).

32. Koo L, Seang K. Inhibitory effect of protoberberine alkaloids from the roots of Coptis japonica on chatecolamine biosynthesis in PC12 cells. PlantaMedica 62(1), 31-34 (1996)

33. Kuo CL, Chi CW, Liu TY. The anti-inflammatory potential of Berberine in vitro and in vivo. Cancer Letters 203(2), 127-137 (2004).

34. Lengauer T, Rarey M. Computational methods for biomolecular docking. Current Opinion in Structural Biology 6(3), 402-6 (1996). DOI:10.1016/S0959-440X(96)80061-3

35. Loconte, H. 1993. Berberidaceae. The Families and Genera of Vascular Plants. II.
Flowering Plants-Dicotyledons.(Eds.): K. Kubitzki, J.G. Rohwer \& V. Bittrich. SpringerVerlag: Berlín.

36. Loconte, H., \& Blackwell Jr, W. H. Berberidaceae of Ohio. Castanea, 39-43 (1984).

37. Lozada, M., Ladio, A. \& Weigandt, M. Cultural transmission of ethnobotanical knowledge in a rural community of northwestern Patagonia, Argentina. Econ. Bot., 60, 374ñ385 (2006).

38. Makkar, H. P. S., Francis, G., \& Becker, K. Bioactivity of phytochemicals in some lesserknown plants and their effects and potential applications in livestock and aquaculture production systems (2007).

39. Monteiro JM, Albuquerque AP, Lins-Neto EMF, Araújo EL, Amorim ELC . Use patterns and knowledge of medicinal species among two rural communities in Brazil's semi-arid northeastern region. J Ethnopharmacol 105: 173-186 (2006).

40. Muthu, C., Ayyanar, M., Raja, N., \& Ignacimuthu, S. Journal of Ethnobiology and Ethnomedicine. Journal of Ethnobiology and Ethnomedicine, 2, 43 ((2006)).

41. Perveen, A, Qaiser, M. Pollen flora of Pakistan-LXV. berberidaceae. Pakistan Journal of Botany, 42(1), 1-6 ((2010)).

42. Phillips, O., \& Gentry, A. H. The useful plants of Tambopata, Peru: I. Statistical hypotheses tests with a new quantitative technique. Economic Botany, 47(1), 15-32 (1993).

43. Pie, S.J. and N.P. Manandhar. Sources of some local medicine in the Himalayan region. Himalayan Ecosys. p. 97-112 (1987).

44. Pieroni, A., C. Quave, and R. Santoro. Folk pharmaceutical knowledge in the territory of the Dolomiti Lucane, inland southern Italy. Journal of Ethnopharmacology 95: 373-384 (2004).

45. Qureshi RA, Ahmah I, Ishtiaq M. Ethnobotany and phytosociological studies of Tehsil Gugar Khan district Rawalpindi, Pakistan. Asian J. Plant Sci., 5(5): 890-893 (2006).

46. Reynolds, S. G., Batello, C., Baas, S., \& Mack, S. Grassland and forage to improve livelihoods and reduce poverty. Grassland: A global resource. Wageningen Academic Publishers, Wageningen, the Netherlands, 323-338 (2005). 
47. Roe, D., \& Elliott, J. Poverty reduction and biodiversity conservation: rebuilding the bridges. Oryx, 38(02), 137-139 (2004).

48. Scherl, L. M. (Ed.). Can protected areas contribute to poverty reduction?: opportunities and limitations. IUCN (2004).

49. Shanley, P. and N. A. Rosa. Eroding knowledge: An ethnobotanical inventory in eastern Amazonia's logging frontier. Economic Botany 58: (2)135-160 (2004).

50. Sheng-Ji, P. Ethnobotanical approaches of traditional medicine studies: some experiences from Asia. Pharmaceutical biology, 39(s1), 74-79 (2001).

51. Sher, H., \& Hussain, F. Ethnobotanical evaluation of some plant resources in Northern part of Pakistan. African journal of Biotechnology, 8(17) (2009).

52. Singh, N., Gupta, M., Sirohi, P., and Varsha. Effects of alcoholic extract of Momordica charantia (Linn.) whole fruit powder on the pancreatic islets of alloxan diabetic albino rats. Journal of Environmental Biology. 29: 101-106 (2008).

53. Taylor, J. L. S., Rabe, T., McGaw, L. J., Jäger, A. K., \& Van Staden, J. Towards the scientific validation of traditional medicinal plants. Plant
Growth Regulation, 34(1), 23-37 (2001).

54. Turner NJ, Turner K. "Where our women used to get the food": cumulative effects and loss of ethnobotanical knowledge and practice; case study from coastal British Columbia. Botany 86: 103-115 (2008).

55. Villinski RJ, Dumas ER, Chai HB, Pezzuto JM, Angerhofer CK, Gafner S. Antibacterial activity and alkaloid content of Berberis thunbergii, Berberis vulgaris and Hydrastiscanadensis. Pharmaceutical Biology 41( 8) , 551-557 (2003).

56. Virk AT, Sheikh KM, Marwat AH. NASSD Background Paper: Biodiversity. IUCN Pakistan, Northern Areas Progamme, Gilgit. x+74 pp. Retrieved from https://cmsdata.iucn. org/downloads/bpbiodiversity.pdf on April 7, 2014.

57. Zent, S. 2001. Acculturation and ethnobotanical knowledge loss among the Piaroa of Venezuela: Demonstration of a quantitative method for the empirical study of traditional ecological knowledge change. In On biocultural diversity: Linking language, knowledge, and the environment. Maffi, L., editor. 190-211.Washington, D.C Smithsonian Institution Press. 